\title{
Arabidopsis AT2G02870 Loss of Function Mutants Lead to Enhanced Production of Hydroperoxide Lyase Pathway Genes and Products \\ (Mutan Fungsi-Hilang Arabidopsis AT2G02870 Membawa kepada Peningkatan Gen dan Produk Tapak Jalan Hidroperoksida Liase)
}

\author{
MuHAMMAD NAEEM-Ul-HASSAN, ZAMRI ZAINAL, NuR ATHIRAH ABD HAMID, \\ MUHAMMAD SAJAD \& ISMANIZAN ISMAIL*
}

\begin{abstract}
F-box proteins containing variable C-terminal domains make an essential part of SKP1-Cullin-Ring box-F box (SCF) complex. SCF complex catalyzes the final step to link the ubiquitin tag with the target protein, destined for degradation, through F-box protein that confer overall substrate specificity to the complex. In this study, we analyzed the role of At2g02870, a Kelch containing F-box protein from Arabidopsis thaliana, by using reverse genetics strategy. At $2 \mathrm{~g} 02870$ loss of function mutant lines (at2g02870) were analyzed and compared with wild type plants for the expression of genes and products of hydroperoxide lyase (HPL) branch of oxylipin pathway. We found that the at $2 \mathrm{~g} 02870$ plants have enhanced expression of HPL pathway genes and produce more green leaf volatiles (GLV) than the wild type plants. Our results suggested that the gene is involved in the regulation of HPL pathway, possibly through the degradation of enzymes or/ and the regulatory factors of the pathway.
\end{abstract}

Keywords: F-box proteins; hydroperoxide lyase; Kelch-repeat; lipoxygenase; oxylipin

ABSTRAK

Protein kotak $F$ mengandungi pelbagai domain $C$-terminal yang membentuk bahagian penting kompleks SKP-CullinRing box-F box (SCF). Kompleks SCF memangkinkan peringkat akhir pengikatan tag ubiquitin dengan protein sasaran untuk degradasi, melalui protin kotak F yang memberikan kespesifikan substrak secara keseluruhan kepada kompleks. Dalam kajian ini, kami menganalisis peranan At2g02870, protein kotak F yang mengandungi Kelch dari Arabidopsis thaliana menggunakan strategi genetik berbalik. Titisan mutan kehilangan fungsi At2g02870 telah dianalisis dan dibandingkan dengan tumbuhan jenis liar untuk pengekpsresan gen dan produk cabang hidroksiperoksida liase (HPL) tapak jalan oksilipin. Kami dapati tumbuhan at2g02870 telah meningkatkan pengekspresan gen tapak jalan HPL dan menghasilkan lebih banyak bahan meruap daun hijau (GLV) berbanding dengan tumbuhan jenis liar. Keputusan kami menunjukkan gen tersebut terlibat dalam pengawalan tapak jalan HPL, kemungkinan melalui degradasi enzim atau/dan faktor pengawalan tapak jalan tersebut.

Kata kunci: Hidroperoksida liase; Kelch-berulang; lipoksigenase; oksilipin; protein kotak F

\section{INTRODUCTION}

Degradation of regulatory proteins is a routine process in multi-cellular organisms to regulate almost every aspect of metabolism. Labelling the proteins with ubiquitin (Ub) tag is the major post-translational modification by which target proteins undergo repeated conjugation with $\mathrm{Ub}$ to give polyubiquitinated proteins (Hershko 1998; Marino et al. 2012). Subsequently, these Ub labelled proteins undergo degradation through $26 \mathrm{~S}$ proteasome complex. Ubiquitination of proteins is a multi-step process, which is catalysed by 3 different types of enzymes. The Ub-activating enzyme designated as E1 catalyses the activation of Ub in an ATP dependent step. In the second step, activated Ub is linked with E2, the Ub conjugating enzyme. The last step is mutually catalysed by E2 and E3, the Ub ligase enzyme that substitutes a Lysine residue on the target protein with Ub. E3 is the most common among all the above-mentioned enzymes and gained special attention of the researchers due to its importance in the overall process of ubiquitination. A complex of SKP1, Cullin1, an F-box and a Ring box proteins (SCF complex) is the largest as well as, until now the best characterized of all the E3 complexes (Deshaies 1999).

F-box proteins are an emerging group of eukaryotic signalling proteins and considered as one of the largest protein superfamily in the plant kingdom. Majority of the F-box proteins have been identified as an essential component of the SCF complexes (del Pozo \& Estelle 2000). Most of these proteins serve for recruiting the SCF substrate that may undergo either the post-translational modification or degradation by ubiquitin-proteasome system. The chemical structure of F-box proteins consists of an N-terminal conserved F-box domain and a C-terminal domain of one or more highly variable secondary motifs. 
These motifs, including leucine rich-repeats (LRR), WD40repeats, kelch-repeats and other motifs participate in the protein-protein interactions (Kuroda et al. 2002).

Kelch-repeat is a domain of 44-56 amino acid residues and contains a conserved sequence of four hydrophobic amino acids, a Glycine couple, a Tyrosine and a Tryptophan that is mostly separated from Tyrosine by six residues (Li et al. 2004). Four $\beta$-sheets constitute a single Kelch motif that forms a bladed structure and a combination of four or more such blades form a $\beta$-propeller. Kelch-repeat domain is common in F-box proteins and interestingly all of these proteins have been found in the plant kingdom except a few in the animal kingdom. Although functional characterization of several Kelch-repeat containing F-box proteins (KFB) has been reported, most of the proteins from this sub-group remain 'orphan' till date. Members of the KFB protein family have been reported in several recent studies for their roles in different phases of important plant physiological processes to promote growth, development and plant defense (Hassan et al. 2015b).

Oxylipin pathway is one of the major plant defense pathway that causes induction of chemical defense responses resulting in the production of useful secondary metabolites (Griffiths 2015; Hassan et al. 2015a). Phytooxylipins make up a diverse group of bioactive lipids, which are oxidized derivatives of the polyunsaturated fatty acids (PUFAs). Linoleic acid (LA, 18:2 $\Delta^{9,12}$ ) and $\alpha$-linolenic acid (ALA, 18:3 $\Delta^{9,12,15}$ ) serve in plants as the major precursors for the pathway. The products of the pathway include jasmonic acid (JA) and its derivatives produced in the Allene oxide synthase (AOS) branch plus the green leaf volatiles (GLV) produced via hydroperoxide lyase (HPL) and include C6 and C9 aldehydes, alcohols and their acetyl derivatives. GLV are produced and released under various stresses and help the plant to defend against various pathogens and herbivores. Moreover, GLV constitute a major portion of the blend of volatile compounds, which are used for plant-plant and plant-insect interactions (Hassan et al. 2015a).

SKP1 interacting protein 11 (At2g02870) is an Arabidopsis thaliana KFB, containing 467 amino acid residues and a domain of five Kelch-repeats in the C-terminal region. Previous studies have shown that the protein may be induced by several phytohormones, such as ABA and has been found to interact with Arabidopsis SKP1LIKE1 (ASK1) and ASK2 proteins (Li et al. 2016; Oono et al. 2003). In a recent report, the gene was found to negatively regulate the release of GLV by possibly interacting with the transcription factors of the pathway (Naeem-ul-Hassan et al. 2017). In the present study, we characterized the function of $A t 2 \mathrm{~g} 02870$ in the HPL pathway by using the At $2 \mathrm{~g} 02870$ loss-of-function mutants (at $2 \mathrm{~g} 02870$ ). Seeds of the T-DNA inserted mutant lines were obtained from the European Arabidopsis stock center (UNASC). Homozygous mutant lines were screened, grown for 6 weeks and then analyzed for the gene expression levels of HPL pathway and metabolic profiling of the pathway to compare with the wild type plants.

\section{MATERIALS AND METHODS}

\section{PLANT MATERIAL}

Seeds of A. thaliana (ecotype Columbia-0) were provided by Dr Noor Azmi Shaharudin (Faculty of Biotechnology and Bimolecular Sciences, Universiti Putra Malaysia). T-DNA insertion in the At2g02870 region (837,811 - 840,152 bps) of chromosome 2 containing seed stock number 'SALK_019581.24.40.x', with disrupted gene function was purchased from the European Arabidopsis Stock Center (uNASC).

\section{CHEMICALS AND REAGENTS}

All the chemicals, solvents and reagents used in the present work were of analytical or equivalent grade. The reference standards were purchased from the SigmaAldrich (USA). DNeasy Plant Kit was obtained from the QIAGEN (UK) and ProtoScript cDNA Synthesis Kit was purchased from the New England biolabs (MA, USA). Platinum Taq DNA Polymerase, Plant RNA Reagent, DNA ladders and the TURBO DNase were obtained from the Life Technologies (CA, USA). qPCR Kit, KAPA SYBR FAST and the KAPA Taq Polymerase were from Kapa Biosystems (Massachusetts).

\section{MOLECULAR ANALYSIS OF MUTANT AND WILD TYPE A. THALIANA PLANTS}

About $100 \mathrm{mg}$ leaf material from 2 weeks old putative at 2 02870 plants was used for the isolation of genomic DNA (gDNA) from each plant with the Qiagen kit following the manufacturer's procedure. Homozygous mutant lines were screened by PCR with KAPA polymerase master mix, using a combination of T-DNA-specific primers plus At2g02870 gene specific primers. PCR product was subsequently analyzed by $1 \%$ agarose gel electrophoresis.

Homozygous mutant plants, confirmed by PCR analysis, along with the wild type $A$. thaliana plants were grown to carry out the molecular characterization. The plants were grown for 40 days under the standard conditions (Temperature $22^{\circ} \mathrm{C}$, light intensity $100-150$ $\mu \mathrm{M} / \mathrm{m}^{2} \mathrm{~s}$ fluorescent light, light period $16 \mathrm{~h}$ day $/ 8 \mathrm{~h}$ night and relative humidity of $50-70 \%$ ) and then the samples were collected (Hong et al. 2010). Two hours before collecting the samples, an aqueous solution of $250 \mu \mathrm{M}$ methyl jasmonate was sprayed to treat the plants in order to activate the expression of defence related genes and to maximize the release of plant defence compounds. Then sampling for the RT-qPCR and for the SPME-GC-MS analysis was done.

\section{GENE EXPRESSION ANALYSIS}

Total RNA extraction was carried out from a few healthy leaves by using the Plant RNA reagent followed by DNA decontamination through Turbo DNA-free kit (Life Technologies). The cDNA templates were prepared for RT-qPCR by reverse transcription of $1 \mu \mathrm{g}$ total RNA using 
an oligo $\mathrm{d}(\mathrm{T})_{23}$ primer and $\mathrm{M}-\mathrm{MuLV}$ reverse transcriptase (NEB). Three lines of AtSKIP11 mutant plants were used for quantification and the analysis was accomplished in triplicate for each line. Arabidopsis genes, including Actin2 (Act2), At2g02870, LOX2, ADH1 and HPL were analyzed for their expression by running RT-qPCR using a qPCR Kit from kapa Biosystems (USA) with a pair of primers for each gene (Table 1) following a previously published protocol (Naeem-ul-Hassan et al. 2017).

\section{GC-MS ANALYSIS OF GLV}

Fully developed leaves of six weeks old Arabidopsis plants were cut with a razor blade to proceed for the extraction and analysis of GLV. Analysis of the GLV formed from at $2 g 02870$ plants and the wild type plants was performed by following a couple of previously published protocols (Matsui et al. 2012; Naeem-ul-Hassan et al. 2017). Briefly, 1-2 $\mathrm{g}$ of healthy Arabidopsis leaves were crushed in $20 \mathrm{~mL}$ glass vials containing glass beads to cause the maximum release of GLV. After sealing the vials with parafilm and the crimp top caps, an SPME fiber (50/30 mm DVB/ Carboxen/
PDMS, Sigma-Aldrich, USA) was exposed to the headspace of the vials for $30 \mathrm{~min}$ at $40^{\circ} \mathrm{C}$. Then this SPME fibre was inserted into the insertion port of a Gas Chromatograph (Agilent 7890A) with a $0.25 \mathrm{~mm} 30 \mathrm{~m} \mathrm{BP} 20$ (WAX) column (SGE Analytical Science, Australia). This GC machine was directly coupled with MS of an Agilent 5975C inert MSD containing triple-axis detector. The injector and interface temperatures were set at $200^{\circ} \mathrm{C}$ and $230^{\circ} \mathrm{C}$, respectively. The analysis was performed by splitless injection with following column temperature program: $40^{\circ} \mathrm{C}$ for $1 \mathrm{~min}$, then rising at a rate of $15^{\circ} \mathrm{C}$ per min up to $230^{\circ} \mathrm{C}$ and finally keep here for $1 \mathrm{~min}$. Library search was employed to find the peaks using NIST/EPA/NIH version 2.0 followed by computing the results in a single peak table.

\section{RESULTS AND DISCUSSION}

\section{EXPRESSION OF HPL PATHWAY GENES IS UP-REGULATED} IN THE MUTANT PLANTS

Two homozygous mutant lines were selected for the analysis by running the PCR of gDNAs of 6 weeks old

TABLE 1. Primers used in qPCR

\begin{tabular}{clc}
\hline Target gene/ primers & Sequence $\left(5^{\prime}-3^{\prime}\right)$ & Amplicon size \\
\hline Act2- F & CTTGCACCAAGCAGCATGAA & 68 \\
Act2-R & CCGATCCAGACACTGTACTTCCTT & \\
at 2 g02870-F & GCCTCTTGTTGCGGTTGTGA & 124 \\
at 2 g02870-R & GCCAGCTCTTTCAGGCAATCTT & \\
Lox2-F & CGTGCACGCCAAAGTCTTGTCAA & 130 \\
Lox2-R & CGGGTAAGCCTTCCTGGTCAA & \\
Hpl-F & CGC ACG TGC GAG GAAAGA & \\
Hpl-R & CGG CTG ATA ACC ACA AAG AAG CTC A & 130 \\
Adh-F & GGAGTGGAGTACAGCTTCGAGTGT & \\
Adh-R & GGATAGGGAGAAGCTGTGGGCTT & \\
\hline
\end{tabular}

Relative Gene Expression in at2g02870 Plants

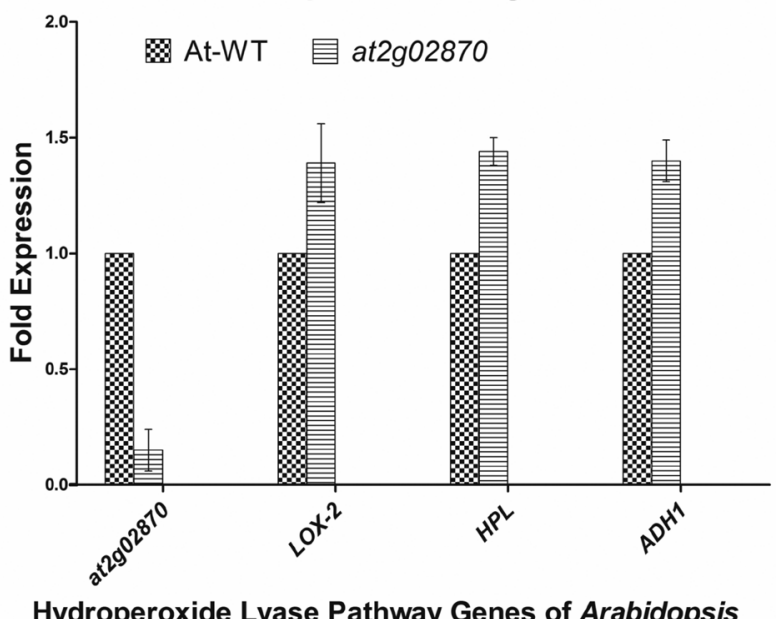

FIGURE 1. Graphical presentation of the changes in expression levels of At2g02870 gene and the oxylipin genes in the at $2 \mathrm{~g} 02870$ plants compared with the wild type plants 
plants by using SALK primers followed by $1 \%$ agarose gel electrophoresis analysis (Appendix S1). The cDNAs of at $2 g 02870$ lines and the wild type plants were used as the templates to calculate any difference in the gene expression levels by RT-qPCR. Relative gene expression was calculated for the HPL pathway by applying the $2^{-\Delta \Delta C t}$ method and the difference in the levels of target gene expression were calculated (Appendix-S2). Figure 1 shows the relative gene expression levels between the mutant and the wild-type plants. Results show an up-regulation of $L O X 2, A D H 1$ and $H P L$ gene expression to about 1.5-fold in the mutant plants compared with the wild type plants. Due to T-DNA insertion in the At2g02870 region, downregulation of the At $2 \mathrm{~g} 02870$ gene to more than 6-fold was recorded in the mutant plants as compared with the wild type plants (Figure 1).

\section{PRODUCTION OF GLV IS ENHANCED IN THE MUTANT PLANTS}

Different GLV were extracted through SPME from the fresh leaf samples of both mutant plants and the control plants and then analysed by GC-MS. Very well resolved peaks with similar patterns were obtained for different GLV in the GC-MS chromatograms Figure 2.

Amounts and the RSD values of various GLV were determined from the respective chromatograms given by control plants and the at $2 \mathrm{~g} 02870$ plants by calculating the mass abundance of these GLV compounds per gram of the leaf material (Table 2).

Comparison of the GLV levels produced in the mutant plants and the control plants was made by plotting the amounts of various GLV per gram of the leaf material along with their RSD values in a graph (Figure 3).

GLV biosynthesis was found to be raised in the at2g02870 plants for almost all the target compounds. Highest increase was observed in the formation of C6 aldehyde hexanal, which was found to be $130 \%$ higher in the mutant plants than the wild type plants, followed by C5 and C6 alcohols (Z)-2-Penten-1-ol, 1-Penten-3-ol and 1 -Hexanol to about $34.6 \%, 27 \%$ and $20 \%$, respectively. However, (Z)-3-Hexen-1-ol was measured to be just about $1 \%$ higher in the at $2 g 02870$ plants as compared with the wild type plants (Figure 3 ).

Evaluating the gene function through reverse genetics strategy has been developed as an important experimental approach. The method mainly relies on the availability of knockout mutant lines for the gene of interest. Either T-DNA or transposable elements can be used for performing the insertional mutagenesis, but in Arabidopsis, the former has been more commonly employed. Primary objective for working with insertional mutant lines is to investigate whether the respective insertion results in a partial or rather a complete loss of gene function. The effect of the insertion largely depends

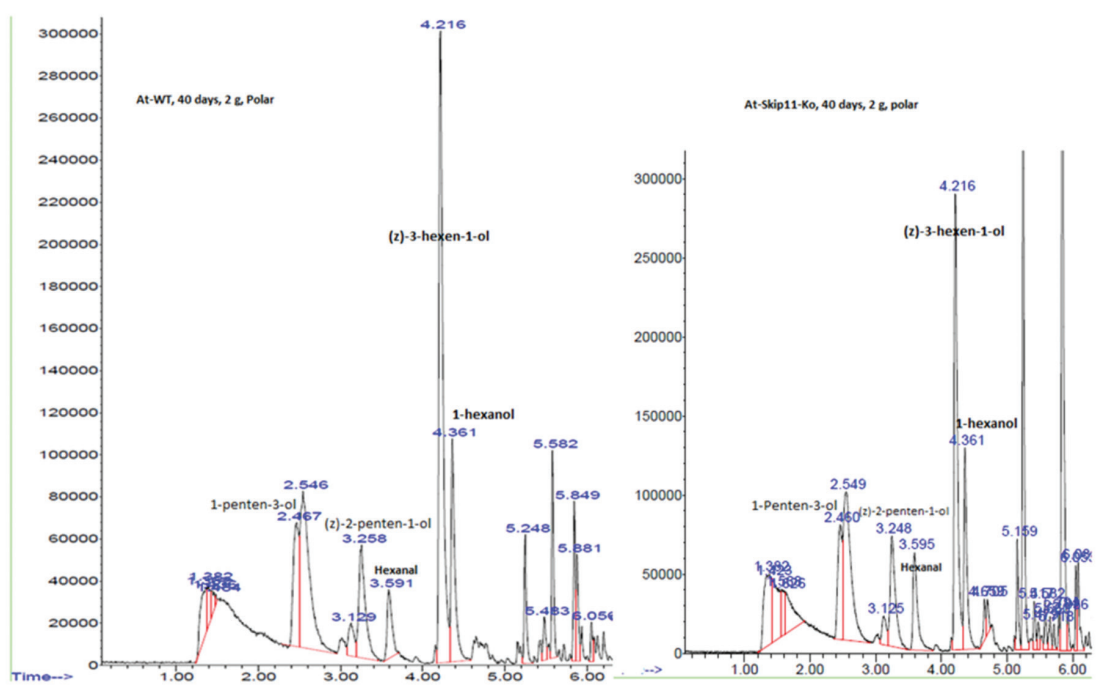

FIGURE 2. SPME-GC-MS profiling of Arabidopsis plants for GLV, wild type VS at $2 g 02870$ plants

TABLE 2. Retention times and the abundance of different GLV in the At-WT plants and the at $2 g 02870$ plants, obtained by averaging the data from GC-MS chromatograms

\begin{tabular}{lccc}
\hline GLV & RT (min.) & At-WT Plants & at2g02870 Plants \\
\hline 1-Penten-3-ol & 2.47 & 1368941 & 1741167 \\
(Z)-2-Penten-1-ol & 3.26 & 1539604 & 2072533 \\
Hexanal & 3.59 & 672029 & 1551387 \\
(Z)-3-Hexen-1-ol & 4.22 & 5161021 & 5213132 \\
1-Hexanol & 4.36 & 1833852 & 2199664 \\
\hline
\end{tabular}




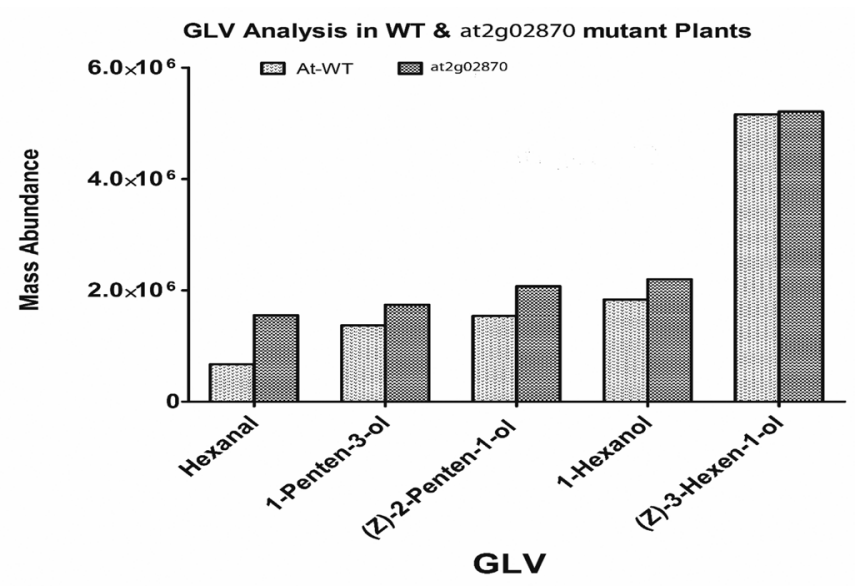

FIGURE 3. Relative abundance of different GLV per gram of fresh leaf material in mutant plants and the control plants

on its position with respect to the structure of the gene (Alonso \& Ecker 2006; Parinov et al. 1999).

Results of the present study suggested involvement of At2g02870 gene in a 'negatively regulating' manner at some stage in the GLV biosynthetic pathway, i.e. reduced expression of the At $2 g 02870$ gene results in the up-regulation of GLV production and vice versa. This is exactly in accordance with our previous results, where the AtSKIP11 gene function was disrupted by antisense cloning of the gene (Naeem-ul-Hassan et al. 2017). Moreover, some other KFB have also been found to take part in the plant development through degradation of the pathway inhibitors. For example, a couple of rice KFB, including Inhibitor for brown furrows 1 (IBF1) and the LARGER PANICLE (LP) were found to negatively regulate the flavonoids biosynthesis and panicle architecture, respectively (Li et al. 2011; Shao et al. 2012). Similarly, members of kiss me deadly (KMD), a group of KFB family of proteins, were found to participate in the regulation of phenylpropanoid biosynthesis and the cytokinin signalling in Arabidopsis. These KFB group members were suggested to physically interact, as a part of the $\mathrm{SCF}^{\mathrm{KMD}}$ complex, with some of the crucial transcription factors and possibly leading to the degradation of the transcription activators, so negatively regulate the signalling processes (Kim et al. 2013; Zhang et al. 2015, 2013).

\section{CONCLUSION}

From the results of the present study, it is concluded that the enzymes of the HPL pathway or the transcription factors interact with the $\mathrm{SCF}^{\mathrm{At2} 202870}$ complex. In the loss of function mutant plants, formation of $\mathrm{SCF}^{\mathrm{A} 22 \mathrm{~g} 02870}$ complex is less than the wild type plants due to reduced expression of the At $2 \mathrm{~g} 02870$ gene. Consequently, interaction of the regulatory proteins, most probably the transcription promoters and the $\mathrm{SCF}^{\mathrm{At2g} 202870}$ complex is also diminished. As a result, reduced or retarded degradation of these regulatory proteins allows an up-regulation of HPL pathway gene expression and the production of enhanced quantities of GLV (Figures 1 and 3).

\section{ACKNOWLEDGEMENTS}

We thankfully acknowledge the UKM for funding this project through FRGS/1/2015/SG03/01/1 grant. The authors declare no conflicts of interest.

\section{REFERENCES}

Alonso, J.M. \& Ecker, J.R. 2006. Moving forward in reverse: Genetic technologies to enable genome-wide phenomic screens in Arabidopsis. Nature Reviews Genetics 7(7): 524.

del Pozo, J.C. \& Estelle, M. 2000. F-box proteins and protein degradation: An emerging theme in cellular regulation. Plant Molecular Biology 44(2): 123-128.

Deshaies, R. 1999. SCF and cullin/ring h2-based ubiquitin ligases. Annual Review of Cell and Developmental Biology 15(1): 435-467.

Griffiths, G. 2015. Biosynthesis and analysis of plant oxylipins. Free Radical Research 49(5): 565-582.

Hassan, M.N., Zainal, Z. \& Ismail, I. 2015a. Green leaf volatiles: Biosynthesis, biological functions and their applications in biotechnology. Plant Biotechnology Journal 13(6): 727-739.

Hassan, M.N.U., Zainal, Z. \& Ismail, I. 2015b. Plant Kelch containing f-box proteins. RSC Advances 5(53): 4280842814.

Hershko, A. 1998. The ubiquitin system. In Ubiquitin and The Biology of the Cell, edited by Peters, J.M., Harris, J.R. \& Finley, D. Boston, MA: Springer. pp. 1-17.

Hong, S.Y., Kim, O.K., Kim, S.G., Yang, M.S. \& Park, C.M. 2010. Nuclear import and DNA binding of the zhd5 transcription factor is modulated by a competitive peptide inhibitor in Arabidopsis. Journal of Biological Chemistry M110. 167692.

Kim, H.J., Chiang, Y.H., Kieber, J.J. \& Schaller, G.E. 2013. $\mathrm{SCF}(\mathrm{kmd})$ controls cytokinin signaling by regulating the degradation of type-b response regulators. Proceedings of the National Academy of Sciences of The United States of America 110(24): 10028-10033.

Kuroda, H., Takahashi, N., Shimada, H., Seki, M., Shinozaki, K. \& Matsui, M. 2002. Classification and expression analysis of Arabidopsis f-box-containing protein genes. Plant \& Cell Physiology 43(10): 1073-1085. 
Li, M., Tang, D., Wang, K., Wu, X., Lu, L., Yu, H., Gu, M., Yan, C. \& Cheng, Z. 2011. Mutations in the f-box gene larger panicle improve the panicle architecture and enhance the grain yield in rice. Plant Biotechnology Journal 9(9): 1002-1013.

Li, X., Zhang, D., Hannink, M. \& Beamer, L.J. 2004. Crystal structure of the Kelch domain of human keap1. Journal of Biological Chemistry 279(52): 54750-54758.

Li, Y., Liu, Z., Wang, J., Li, X. \& Yang, Y. 2016. The Arabidopsis Kelch repeat f-box e3 ligase arkp1 plays a positive role for the regulation of abscisic acid signaling. Plant Molecular Biology Reporter 34(3): 582-591.

Marino, D., Peeters, N. \& Rivas, S. 2012. Ubiquitination during plant immune signaling. Plant Physiology 160(1): 15-27.

Matsui, K., Sugimoto, K., Mano, J.I., Ozawa, R.\& Takabayashi, J. 2012. Differential metabolisms of green leaf volatiles in injured and intact parts of a wounded leaf meet distinct ecophysiological requirements. PLoS One 7(4): e36433.

Naeem-ul-Hassan, M., Zainal, Z., Kiat, C.J., Monfared, H.H. \& Ismail,I. 2017. Arabidopsis thaliana skp1 interacting protein 11 (at $2 \mathrm{~g} 02870$ ) negatively regulates the release of green leaf volatiles. RSC Advances 7(88): 55725-55733.

Oono, Y., Seki, M., Nanjo, T., Narusaka, M., Fujita, M., Satoh, R., Satou, M., Sakurai, T., Ishida, J. \& Akiyama, K. 2003. Monitoring expression profiles of Arabidopsis gene expression during rehydration process after dehydration using ca. 7000 full-length cdna microarray. The Plant Journal 34(6): 868-887.

Parinov, S., Sevugan, M., Ye, D., Yang, W.C., Kumaran, M. \& Sundaresan, V. 1999. Analysis of flanking sequences from dissociation insertion lines: A database for reverse genetics in Arabidopsis. The Plant Cell 11(12): 2263-2270.

Shao, T., Qian, Q., Tang, D., Chen, J., Li, M., Cheng, Z. \& Luo, Q. 2012. A novel gene ibf1 is required for the inhibition of brown pigment deposition in rice hull furrows. Theoretical and Applied Genetics 125(2): 381-390.

Zhang, X., Gou, M. \& Liu, C.J. 2013. Arabidopsis Kelch repeat f-box proteins regulate phenylpropanoid biosynthesis via controlling the turnover of phenylalanine ammonia-lyase. Plant Cell 25(12): 4994-5010.
Zhang, X., Gou, M., Guo, C., Yang, H. \& Liu, C.J. 2015. Downregulation of Kelch domain-containing f-box protein in Arabidopsis enhances the production of (poly) phenols and tolerance to ultraviolet radiation. Plant Physiology 167(2): 337-350.

Muhammad Naeem-ul-Hassan, Zamri Zainal \& Ismanizan Ismail*

Centre for Biotechnology and Functional Food

Faculty of Science and Technology

University Kebangsaan Malaysia 46300 Bangi UKM, Selangor Darul Ehsan Malaysia

Zamri Zainal, Nur Athirah Abd Hamid, Muhammad Sajad \& Ismanizan Ismail*

Institute of Systems Biology (INBIOSIS)

University Kebangsaan Malaysia 46300 Bangi UKM, Selangor Darul Ehsan Malaysia

Muhammad Naeem-ul-Hassan

Department of Chemistry

University of Sargodha, Sargodha

Pakistan

Muhammad Sajad

Department of Plant Breeding and Genetics

University College of Agriculture and Environmental Sciences The Islamia University of Bahawalpur

Pakistan

*Corresponding author; email: maniz@ukm.edu.my

Received: 30 May 2018

Accepted: 19 September 2018 